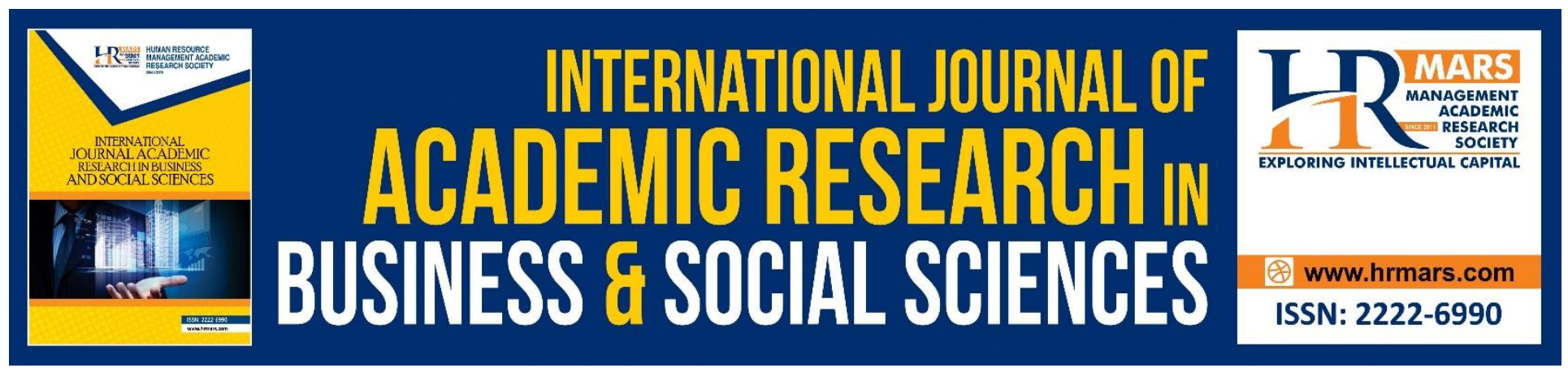

\title{
The Impact of Information and Communication Technology on Procurement Performance in Manufacturing Firms in Kenya
}

Nicholas Chengeh Cheptora, Anthony Osoro, Enock Gideon Musau

To Link this Article: http://dx.doi.org/10.6007/IJARBSS/v8-i9/4641 $\quad$ DOI: $10.6007 /$ IJARBSS/v8-i9/4641

Received: 06 August 2018, Revised: 27 August 2018, Accepted: 29 Sept 2018

Published Online: 15 October 2018

In-Text Citation: (Cheptora, Osoro, \& Musau, 2018)

To Cite this Article: Cheptora, N. C., Osoro, A., \& Musau, E. G. (2018). The Impact of Information and Communication Technology on Procurement Performance in Manufacturing Firms in Kenya. International Journal of Academic Research in Business and Social Sciences, 8(9), 605-616.

\section{Copyright: (c) 2018 The Author(s)}

Published by Human Resource Management Academic Research Society (www.hrmars.com)

This article is published under the Creative Commons Attribution (CC BY 4.0) license. Anyone may reproduce, distribute, translate and create derivative works of this article (for both commercial and non-commercial purposes), subject to full attribution to the original publication and authors. The full terms of this license may be seen at: http://creativecommons.org/licences/by/4.0/legalcode

Vol. 8, No. 9, September 2018, Pg. 605 - 616

Full Terms \& Conditions of access and use can be found at http://hrmars.com/index.php/pages/detail/publication-ethics 


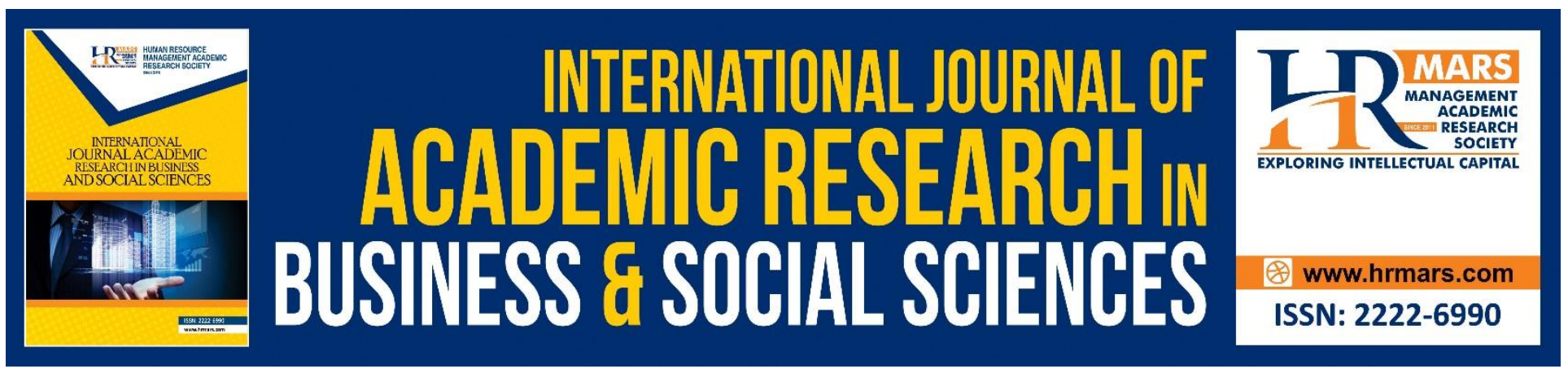

\title{
The Impact of Information and Communication Technology on Procurement Performance in Manufacturing Firms in Kenya
}

\author{
Nicholas Chengeh Cheptora
}

Candidate Masters of Science in Procurement and Logistics, Jomo Kenyatta University of Agriculture and Technology, School of Entrepreneurship, Procurement and Management, Nairobi, Kenya

Email:nickchengeh@yahoo.com

\section{Dr. Anthony Osoro (PhD)}

Lecturer Jomo Kenyatta University of Agriculture and Technology, School of Entrepreneurship,

Procurement and Management, Nairobi, Kenya

Email:ansoroh@gmail.com

\section{Dr. Enock Gideon Musau (PhD)}

Lecturer Jomo Kenyatta University of Agriculture and Technology, School of Entrepreneurship,

Procurement and Management, Nairobi, Kenya

Email:egiddy14@gmail.com

\begin{abstract}
Despite the great impact that the industrial segment plays in the Kenyan economy it is still faced with challenges. The main objective was to establish the factors affecting procurement performance in manufacturing firms in Kenya, a case of Nzoia sugar company Ltd. The study sought to establish whether all the four independent variables that include, Managerial style, Information communication technology, employee competency and procurement policy had significance to the procurement performance. The study was conducted using a descriptive research design with a target population of 526 respondents, which translated to a sample size of 220 from Procurement, Finance, Human Resource, General administration and information communication technology departments. The study anchored variables on different theories for which 5-point Likert scale questionnaire was the main instrument of data collection for the study and data collected 'analyzed using SPSS version 24. Findings indicated Nzoia Sugar Company Ltd lacks a good ICT infrastructure, leans more towards autocratic leadership and hardly adheres to procurement policy. On exploration of prevailing initiatives to address employee competence, it was found out that employee
\end{abstract}


competency was not a priority. The study concluded that managerial style remains central to procurement performance and thus employee involvement is paramount and has direct impact on procurement performance of manufacturing firms. Thus the autocratic leadership style adopted has failed to foster communication and collective participation resulting to poor performance. On addition, procurement policy is crucial for fostering procurement processes of which most of manufacturing firms remain lax on such policies that eventually results in poor procurement performance. Also technical competence of procurement personnel is fundamental for procurement performance therefore there is need to have continued education and development of procurement personnel. The study recommended that there is need to adopt a participatory managerial style that can encourage quick and efficient accomplishment of procurement role and adoption of EDI to streamline the procurement process. In addition, the research recommends that the firm come up with mechanisms that will boost growth and development of employees and enforce compliance of procurement policy.

\section{Introduction}

Procurement performance is an on-going, never-ending, integrated process requiring continuous reassessment and reformation. Procurement is the nerve center of performance in every institution, whether public or private and thus needs a tight system to be followed and adopted. Procurement performance measurement is the process by which procurement establishes criteria, based on strategic planning goals, for determining the results and quality of its activities. It involves creating a simple, effective system for determining whether the procurement is meeting its objectives (Wanyonyi\&Muturi, 2015).This includes monitoring results, comparing to benchmarks and best practices, evaluating the efficacy and efficiency of the process, controlling for variances, and making adjustments to the process as necessary (Kerzner, \&Kerzner, 2017).

\section{Statement of the Problem}

Despite the core role that the manufacturing sector plays in the economic prosperity of the country, evidence shows that the industry is awash with challenges ranging from legal to monetary (Anzetse, 2016; Ogot, 2014). Besides, studies have shown that the manufacturing experiences challenges in terms of procurement processes that in turn affects procurement performance (Moenga, 2011; Osoro, 2016). Interest among industry stakeholders and researchers ought to focus more on this industry that is vital to the country's economy, with a view to discerning factors that are deterring its growth. The present study, therefore, examined factors affecting procurement performance (viewed as an antecedent to sector growth)in manufacturing firms, and in particular Nzoia Sugar Company Limited.

Evidence in extract literature shows that manufacturing firms in Kenya have been facing a variety of challenges, Anzetse (2016) for instance argues that manufacturing firms in Kenya are relatively underdeveloped considering that their growth has on average been growing at a rate lower than the economy.According to Ogot (2014), informal sector micro-enterprises allied to the manufacturing sector experience challenges in form of inadequate capital, production cost, and competition. 
According to (Moenga, 2011) study on procurement and supply chain practices and performance of small scale tea sector in Kenya; found that the challenges affecting the sector were procurement performance and supply chain visibility, increasing customer demands, risk management, globalization and cost containment. In order to attain optimal procurement performance, various factors have to be taken into consideration by firms. Most available are from developed countries and the few available does not touch the areas of my study. The study is done in Kenyan context order to bridge the gap. In view of the foregoing this tends to bridge the gap by creating new knowledge to enhance the better performance of manufacturing in Kenya; most importantly the procurement performance to improve in these firms.

\section{Objective of the study}

The objective of this study was to evaluate the impact of information communication technology on procurement performance in Nzoia sugar Company.

\section{Research Question}

What is the effect of information communication technology on procurement performance in Nzoia sugar Company?

\section{LITERATURE REVIEW}

The study was guided by planned behavior theory.

\section{Theory of Planned Behavior}

According to Ajzen, (1991) the dominant issue in the Theory of Planned Behaviour (TPB) is the person's purpose to execute a particular act that is improved the Theory of Planned Behaviour. The sturdier the purpose to involve in the act, thus the yield would result in more output as opposed to not achieving. TPB hunches that a person's aim is to act in a certain way guided by three aspects: determinants: boldness, individual norm, and apparent action mechanism. The significance of the factors would vary across the various happenings (Ajzen and Fishbein, 1980).

The way a person acts portrays their negative and positive attributes in life. This is seen by their attributes on how they perform at work. The individual is subjected to adaptable behaviour's. at the very end the last factor is called the perceived behavior control. Thus TPB forecasts how one would act in their life as such they would be some level of conforming to certain aspects in life such as how one perceives issues and using them as a management function showing an element of professionalism. An individual therefore should be courageous and also show that they are in control with how they act in life. The hypothesis is used in the acceptance of the acceptable behaviours that can be incorporated in the procurement systems of which is in line with the services that are provided for instance Nzoia Sugar Company Ltd.

A number of researchers allude to the aspect of the TPB to be more focused on mental processing capabilities. The theory has been critiqued on that basis. Some academicians have also levelled accusations on the theory being self-vested as opposed to focusing on the needs of an individual. For instance a person with the right attitude might want to feed on beef but order another type of food when hungry. 
INTERNATIONAL JOURNAL OF ACADEMIC RESEARCH IN BUSINESS AND SOCIAL SCIENCES Vol. 8, No. 9, Sept. 2018, E-ISSN: 2222-6990 @ 2018 HRMARS

In another perspective a person might abhor taking alcohol yet they have very little intent to drink. These persons will still have the opportunity of taking alcohol in order to seek approval of a certain group (Mai, 2016).

Theory of planned behaviour is thought to be relevant for this study since it focuses on individuals behaviour and explicit to use ICT respectively. In addition the TPB theory establishes the nexus between data and communication technology and the enactment of industrial firms in Kenya; hence it gives a theoretical background for this study.

\section{CONCEPTUAL FRAMEWORK}

To implement these study independent and dependent variables was defined for the conceptual framework.

\begin{tabular}{|c|c|}
\hline ndependent Variable & Dependent Variable \\
\hline \multirow{2}{*}{$\begin{array}{l}\text { Information and } \\
\text { Communication Technology }\end{array}$} & \multirow{2}{*}{$\begin{array}{l}\text { Procurement performance in manufacturing } \\
\text { firms }\end{array}$} \\
\hline & \\
\hline - E-Procurement & - Customer satisfaction \\
\hline$\bullet \mathrm{EDI}$ & - Reduced lead time \\
\hline & $\begin{array}{l}\text { - Competitive } \\
-1 \ldots \ldots+1 \\
\end{array}$ \\
\hline
\end{tabular}

\section{Information and Communication Technology}

Electronic procurement in the broadest sense refers to $\mathrm{B} 2 \mathrm{~B}$ or $\mathrm{B} 2 \mathrm{C}$ or $\mathrm{B} 2 \mathrm{G}$ that being the buying and selling of supplies, labour, and facilities such as data network and information mechanisms. This relates to the information exchange and scheduling (Muhia \& Afande, 2015). There are various parts of e procurement which include electronic contracts, data, orders; sourcing. The e procurement can be termed as the process of integrating and streamlining procurement processes through the institution (Muhia \& Afande, 2015).

According to Lysons \& Farrington (2012), EDI is a technique based on agreed standards that facilitate business transactions in the standardized electronic form in an automated manner directly from a computer application to an application in another computer. Data elements and codes are described in a directory relating to the message standard used, thus allowing organizations to trade electronically.Although there are still many EDI standards, only two, namely ASCx12 and EDIFACT are used. The Accredited Standards Committee of the American National StandardsInstitute, which defines data formats and encoding rules for business transactions, created ASCx12 in 1979. United Nations developed EDIFACT (EDI for Administration Commerce and Transport) in 1985 for providing EDI standards that would support world trade, (Lysons \& Farrington 2012). 
According to Monczka, et al., (2009), enterprise resource planning system is an integrated transaction processing and reporting system. The different software applications and forms of ERP support the re-engineering of business processes. Expressed in simpler terms, ERP systems provide the means for tracking organizational resources, including people, processes, and technology. The system serves as the backbone to the organization in terms of providing the information and support required for making decisions. ERP systems add process logic to an organizational information system and create a fundamental discipline in business processes.

Whereas in the past managers and staff were free to make decisions independent of other functional areas, ERP systems effectively force people to interact together in a single system. ERP systems also create a process logic between the closely related areas of customer order management, manufacturing planning and execution, purchasing processes, and financial management and accounting.

Monczka, Handfield, Giunipero, \& Patterson, (2015) did a study on Purchasing and supply chain management stated that EDI was able to replace paperwork used by buyers and sellers for commercial transactions thus enhanced record keeping and faster retrieval and information sharing amongst the business entities. In addition, it has also reduced lead times since the information on reorder levels are usually shared with the prospective suppliers, therefore able to respond immediately when inventory is required. This, in the end, will reduce the cost of inventory and support the realization of JIT (Just -In -Time) strategy and better customer care.

\section{Procurement Performance}

Procurement performance is the backbone of a manufacturing firm success since it contributes to competitive purchase and acquisition of quality goods that put the organization products or services in the competitive edge in the market. However, on several occasions, poor procurement performance has caused a private sector financial loss due to the delivery of poor quality work materials, loss of value for money and inflated prices. Poor procurement performance also contributed to decreasing of profitability of private sector (Juma, 2010). According to Migai(2010), poor procurement performance is a major hindrance to private sector organizations growth since it causes the delay of delivery, increase of defects, delivery of low-quality goods or non-delivery at all (Barsemoi, Mwangagi \& Asienyo, 2014).

According to Barsemoi, Mwangagi \& Asienyo, (2014), performance in the private sector has been a problem due to incompetent staff, traditional procurement procedures, and inability to embrace eprocurement, poor coordination of procurement activities, lack of quality assurance policies and lack of proper regulations (Juma 2010). According to Canon, (2000), lack of established procurement laws in Kenya contribute to 61 percent of losses made in procurement bids. In addition, procurement is a new field and issues such as training and ethical policies are yet to be fully developed in this field. This has worsened the situation, especially in the private sector necessitating a study to examine factors influencing procurement performance in the private sector in Kenya with the view to improve procurement performance. 


\section{RESEARCH METHODOLOGY}

The research design is the basic plan that indicates an overview of the activities that are necessary to execute the research (Mugenda\&Mugenda 2009). The study adopted a descriptive research design since the study intends to gather quantitative and qualitative data that describe the factors that affect procurement performance in manufacturing firms in Kenya. According to Mugenda\&Mugenda (2009), descriptive research was used to obtain information concerning the status of the phenomena to describe, "What exists" with respect to variables or conditions in a situation. The study considered this design to be appropriate since it facilitated the gathering of reliable and accurate data that clearly described the factors that affect procurement performance in manufacturing firms in Kenya.

The target population was the employees of Nzoia sugar company Ltd drawn from the following departments, procurement, production, Finance, General administration and human resource. Based on records retrieved from the human resource department, the total target population was therefore 526 employees.

The data collection instrument used was a questionnaire designed using the variables identified as important for meeting the objectives of the survey. A questionnaire is a printed self-report form designed to elicit information that can be obtained through the written responses of respondents (Mugenda\&Mugenda, 2009). A closed-ended questionnaire was administered to the respondents. The questionnaire was used since it was easy to administer and after obtaining data it was easy to analyze, (Mugenda\&Mugenda, 2009). 5-point Likert scale questionnaire was the main instrument of data collection for the study. After collection of data the researcher conducted data cleaning, which involved the identification of incomplete or inaccurate responses and correct to improve the quality of the responses. The data were coded and entered into the computer for analysis using the Statistical Package for Social Sciences (SPSS), version 24. The research yielded quantitative data.

\section{RESEARCH FINDINGS AND DISCUSSION}

\section{Response Rate}

Questionnaires were administered to the selected sample of 220 employees of the company. A total of 181 questionnaires were returned completely filled. The overall response rate was therefore 82.3\%, which was found suitable for the study, basing on assertions by Saunders, Lewis, \& Thornhill (2009) that a response rate of $50 \%$ is adequate, while that of $70 \%$ is excellent.

Table 4.1 Response Rate

\begin{tabular}{lll}
\hline Questionnaires & Frequency & Percent \\
\hline Male & 135 & 74.6 \\
Female & 46 & 25.4 \\
Total & $\mathbf{1 8 1}$ & $\mathbf{1 0 0}$
\end{tabular}

\section{Information and Communication Technology}

Information and Communication Technology was conceptualized as the second factor that could influence procurement performance. Focus on information communication technology was informed 
INTERNATIONAL JOURNAL OF ACADEMIC RESEARCH IN BUSINESS AND SOCIAL SCIENCES Vol. 8, No. 9, Sept. 2018, E-ISSN: 2222-6990 @ 2018 HRMARS

of the importance of electronic data interchange in facilitating business transactions (Lysons \&Farrangton, 2012). It was therefore prudent to examine the prevailing infrastructure for ICT in Nzoia Sugar Company.

Six items were also used to measure the prevailing infrastructure of ICT integration in procurement functions. The overall mean response score and associated standard deviation $(M=2.30, S D=0.876$ ) indicated a consistent disagreement among employee with regards to the integration of ICT in procurement functions in the company (Table 4.8). Respondents were particularly unhappy with ICT networks and utilization ( $M=2.29, \mathrm{SD}=0.685)$; utilization of $\mathrm{EDI}(\mathrm{M}=2.12, \mathrm{SD}=1.015)$; integration of the ERP system ( $M=2.17, S D=1.008)$; handling of customer orders $(M=2.29, S D=1.062)$; and use of ICT in marketing $(\mathrm{M}=2.36, \mathrm{SD}=0.574)$.

Table 4.8 Integration of Information and Communication Technology

\begin{tabular}{lcc}
\hline Scale Items & M & SD \\
\hline The company has good networks with high levels of ICT utilization & 2.29 & .685 \\
The communication system provides opportunities for suppliers to give & 2.55 & 1.714 \\
feedback & 2.12 & 1.015 \\
EDI has totally replaced paperwork in procurement functions & 2.17 & 1.008 \\
The ERP system has been integrated intothe procurement functions of & 2.17 \\
the company & 2.29 & 1.062 \\
Customer orders are expedited using the ERP system & 2.36 & .574 \\
Use of ICT has improved the marketing potential of the company & $\mathbf{2 . 3 0}$ & .876 \\
Overall response scores &
\end{tabular}

The significance of these results is that the use of ICT in procurement functions in Nzoia Sugar Company appears to have not gained the required momentum. The bottom line is that procurement functions could be missing out on the advantage that EDI integration brings to the procurement process. Indeed e-procurement has been noted to fast-track the procurement process but requires the internet and other ICT systems (Muhia, \&Afande, 2015). ERP, on the other hand, makes it easier to track resources including people and process, but it also requires an elaborate ICT infrastructure.

\section{Model Goodness of fit}

Regression analysis was used to establish the strengths of relationship between performance of procurement (dependent variable) and the predicting variables; managerial style, information and communication technology, employee competency and procurement policy (independent variables). The results showed a correlation value $(R)$ of 0.851 which depicts that there is a good linear dependence between the independent and dependent variables. 
INTERNATIONAL JOURNAL OF ACADEMIC RESEARCH IN BUSINESS AND SOCIAL SCIENCES

Vol. 8, No. 9, Sept. 2018, E-ISSN: 2222-6990 @ 2018 HRMARS

Table 4.13 Model Goodness of Fit

\begin{tabular}{llll}
\hline $\mathbf{R}$ & $\mathbf{R}^{\mathbf{2}}$ & Adjusted $\mathbf{R}^{\mathbf{2}}$ & Std. Error of the Estimate \\
\hline 0.851 & 0.781 & 0.796 & 0.056
\end{tabular}

a. Predictors: (Constants), democratic leadership style, E-procurement, Training, personnel conduct, social and minority business objective.

b. Dependent Variable: Procurement performance in manufacturing firms.

\section{Regression coefficients}

With an R-squared of 0.781 , the model shows that democratic leadership style, E-procurement, training, personnel conduct and social and minority business objectives explain $78.1 \%$ of the variations on performance of manufacturing firms while $21.9 \%$ is explained by other indicators which are not inclusive in this study or model.

The multiple regression coefficients (Table 4.27) indicated that when the four factors were considered together, ICT $(\beta=0.638, p<0.05)$; managerial style $(\beta=0.495, p<0.05)$; and procurement policy $(\beta=0.151, p<0.05$ ) were positive and significant predictors of procurement performance. Employee competence $(\beta=0.085, p>0.05)$ though having minimal positive effects on procurement performance, was however not significant. The implication being that employee competence may not be felt when the four factors are considered in a multiple variable setting. The confirmed multiple regression models can, therefore, are modeled as;

$Y=0.187+0.495 X_{1}+0.638 X_{2}+0.085 X_{3}+0.151 X_{4}+\varepsilon$

Table Error! No text of specified style in document..15Regression Coefficient Results

\begin{tabular}{lccccc}
\hline \multicolumn{7}{c}{ Unstandardized Coefficients } & $\begin{array}{c}\text { Standardized } \\
\text { Coefficients } \\
\text { Model }\end{array}$ & B & Std. Error & Beta & t & Sig. \\
\hline 1 (Constant) & .187 & .065 & & 2.878 & .004 \\
Managerial Style & .420 & .187 & .495 & 2.241 & .026 \\
ICT & .595 & .054 & .638 & 11.059 & .000 \\
Employee Competence & .073 & .190 & .085 & .384 & .701 \\
Procurement Policy & .156 & .059 & .151 & 2.635 & .009 \\
\hline
\end{tabular}

a. Dependent Variable: Procurement Performance

b.Constant: Customer satisfaction, Reduced lead times, Cost reduction, Competitive advantage.

\section{CONCLUSION AND RECOMMENDATIONS}

Use of information communications technology impacts positively on procurement performance in manufacturing firms in Kenya. However, the ICT infrastructure in Nzoia Sugar Company is not elaborate enough to support procurement functions. Integration of electronic data interchange that would see the application of systems such as ERP is still in its nascent stages and does not, therefore, support improved performance in the procurement processes. 
In this era of globalization, companies look for opportunities to remain competitive. The researcher recommends that manufacturing firms in Kenya should look to exploit opportunities that information and communication technology presents. They need to embrace electronic data interchange that will not only streamline procurement processes but will also improve the firms marketing endeavors. Besides, the integration of EDI will also help to expedite customer orders.

The weighty nature of the study requires that future studies be conducted using more manufacturing firms, and which should be distributed across the entire country for proper generalization of the study findings. Relying on only one firm such as was the case in the present study may not give a clear picture of procurement performance in manufacturing firms in Kenya.

The role of background characteristics was not clearly brought out. The study recommends that future studies should try to address the moderating influence of background characteristics on the relationship between the identified factors and procurement performance.

\section{Acknowledgement}

I thank our almighty God for enabling me to reach this far and complete my research study successfully. I would like also to extend my sincere appreciation to my Supervisors Dr. Antony Osoro and Dr. Enock Gideon Musau with whose guidance, support and encouragement this research project has been completed. I also acknowledge the entire University staff that ensured there exist a conducive environment for learning; kindly accept my appreciation for your great support. My gratitude goes to my family and friends; for their unfailing moral support throughout my period of study, understanding and appreciating the demand of the course in terms of time and resources' cannot forget my classmates who influence positively my life and are a source of inspiration throughout my study.

\section{References}

Anzetse, W. (2016). Manufacturing in Kenya: Features, Challenges, andOpportunities. A scoping exercise. Supporting Economic Transformation approach. Nairobi, ACTS Press.

Barsemoi, H., Mwangagi, P., \& Asienyo, B. O. (2014).Factors Influencing Procurement Performance in Private Sector in Kenya. International Journal of Innovation.

Barsemoi, H., Mwangagi, P., \&Asienyo, B.O. (2014). Factors Influencing Procurement Performance in Private Sector in Kenya. International Journal of Innovation and Applied Studies 9(2): 632641.

Canon, J. (2000).Professionalism in Procurement. (1. Ed.) London: Pitman Publishers.

House, R.J. (1971). A path-goal theory of leader effectiveness. Administrative science Quarterly, 16,321-338. 
INTERNATIONAL JOURNAL OF ACADEMIC RESEARCH IN BUSINESS AND SOCIAL SCIENCES

Vol. 8, No. 9, Sept. 2018, E-ISSN: 2222-6990 (C) 2018 HRMARS

House, R.J., \& Mitchell, T.R., (1974).Path-goal theory of leadership Journal of contemporary business, 5, 81-94.

Juma, M. J. (2010), Lead from where you are: Quarterly PPO Bulletin (4)1. Nairobi: A publication of Non-Governmental Organizations Procurement Oversight Authority.

Kerzner, H., \&Kerzner, H. R., (2017). Project management: a systems approach to planning, scheduling, and controlling. John Wiley \& Sons.

Lysons, K., \& Farrington B., (2012), Purchasing and supply chain management, $8^{\text {th }}$ edition, Pearson Financial Times, 687 pgs.

Mai, J. E., (2016). Looking for information: A survey of research on information seeking, needs, and behavior. Emerald Group Publishing.

Moenga, K.O., (2011), Supply chain management practices and challenges for the small scale tea sector in Kenya, Research project.

Monczka R. M., Robert B. H., Larry C. G., \& James L.P.,(2009),Purchasing and supply chain management, South Western Cengage learning.

Monczka, R. M., Handfield, R. B., Giunipero, L. C., \& Patterson, J. L., (2015). Purchasing and supply chain management. Cengage Learning.

Mugenda, O. M. \& Mugenda, A. (2009). Research Method: Qualitative and Quantitative

Muhia D.W., \& Afande F.O.,(2015), Adoption of E-procurement strategy and procurement performance in state corporations in Kenya(A case of KRA),Journal International knowledge sharing platform, Vol.5, No.6.

Mullins, L.J. (2010),Management\& Organizational Behavior, $9^{\text {Th }}$ Edition Financial Times Pitman Publishing.

Ogot, M. (2014). Evidence on Challenges Faced by Manufacturing Informal Sector Micro-Enterprises in Nairobi and Their Relationship with Strategic Choice. International Business Research. 7. 10.5539/ibr.v7n6p119.

Osoro, A., Muturi, W.M.,\&Ngugi, P.K.,(2015),Economic Data Analysis Affecting Performance of Supply Chain Systems in the Petroleum Industries in Kenya.The International Journal of Business \& Management,3(9),98. 
INTERNATIONAL JOURNAL OF ACADEMIC RESEARCH IN BUSINESS AND SOCIAL SCIENCES

Vol. 8, No. 9, Sept. 2018, E-ISSN: 2222-6990 @ 2018 HRMARS

Saunders, M., Lewis, P. and Thornhill, A. (2009). Research Methods for Business Students (5th Ed.). Harlow: Pearson Education Ltd. Schindler, D.C.P. Business Research Methods. McGraw Hill Publishers

Wanyonyi, S. C. \& Muturi, W. (2015). Factors affecting the performance of procurement function among public technical training institutions in Kisumu County,Kenya. International Journal of Economics, Commerce, and Management, 3(5), 1-35 